\title{
Association of ECG early repolarization phenomena and "T-infantile" with autonomic regulation of the heart rhythm in young athletes
}

\author{
Ye. L. Mykhaliuk ${ }^{* 1, A, B, F}$, V. V. Syvolap ${ }^{1, A, E, F}$, L. M. Hunina ${ }^{1, A, E}$, M. S. Potapenko $0^{1, C, E}$, \\ D. Al Kaddah ${ }^{\mathrm{B}, \mathrm{D}}$
}

'Zaporizhzhia State Medical University, Ukraine, ${ }^{2}$ Educational and Scientific Olympic Institute of the National University of Physical Education and Sports of Ukraine, Kyiv

A - research concept and design; B - collection and/or assembly of data; C - data analysis and interpretation; D - writing the article;

$\mathrm{E}$ - critical revision of the article; $\mathrm{F}$ - final approval of the article

Key words:

“T-infantile", young athletes, autonomic balance.

\section{Zaporozhye}

medical journal

2020; $22(3), 356-362$

*E-mail: evg.mikhalyuk@gmail. com
The incidence of autonomic disorders in athletes varies widely from $6.2 \%$ to $36.5 \%$. With the improving sport qualification, the frequency and severity of autonomic dysfunction increase. Various ECG phenomena, including SEVR and "T-infantile" are associated with a type of autonomic tone. Moreover, ANS dysfunction does not determine the genesis, but only contributes to the manifestation of these syndromes signs. The association between the ECG phenomena and autonomic dysfunction nature, age and gender of athletes remains an open question.

The purpose of this work was to study the incidence of juvenile T-wave and SEVR, their association with the autonomic regulation of heart rate in young athletes in the age range between 6 and 17 years.

Materials and methods. An electrocardiographic study and 5-minute recordings of the heart rate variability were carried out in 3720 children and adolescents aged between 6 and 17 years, of them $74.6 \%$ were boys $(n=2774)$ and $25.4 \%$ were girls $(n=946)$, engaged in various sports.

The study results. The "T-infantile" phenomenon was detected in $1.5 \%$ (56/3720) of athletes, among them $1.07 \%(40)$ were boys and $0.43 \%$ (16) were girls. In five (12.5\%) athletes, "T-infantile" was combined with incomplete right bundle branch block, in $3(7.5 \%)$ - with short PQ syndrome, and in one (2.5\%) - with SEVR. In addition to the ECG signs of "T-infantile", three (18.75 \%) athletes additionally had incomplete RBBB, and also short PQ syndrome was detected in one athlete $(6.25 \%)$.

A comparative analysis of HRV indices in boys and girls with the "T-infantile" phenomenon showed that in boys, the D value was significantly higher, reflecting the vagal regulation activity of the heart rhythm $(0.403 \pm 0.028 \mathrm{~s}$ versus $0.311 \pm 0.025 \mathrm{~s}, P=0.019)$. When assessing the autonomic state according to R. M. Baevsky, it was found that $40 \%(n=16)$ of male athletes with T-infantile ECG phenomenon had an increased parasympathetic nervous system tone, $50 \%(n=20)$ had normal ANS tone, and $10 \%(n=4)$ had an increased sympathetic nervous system tone. In girls, there were $31.25 \%(n=5)$ with increased PNS tone, $50 \%(n=8)$ with normal ANS tone and $18.75 \%(n=3)$ with increased SNS tone, respectively.

Conclusions. Early repolarization syndrome and "T-infantile" are more common in case of increased parasympathetic nervous system tone rather than in other variants of autonomic tone. A combination of parasympathetic overactivity with these ECG phenomena is observed mainly in males. The phenomenon of "T-infantile" can be combined with incomplete right bundle branch block in young athletes of both sexes.
Киючові слова: "T-infantile", юні спортсмени, вегетативний

баланс.

Запорізький медичний журнал 2020. T. 22, № 3(120) C. $356-362$

\section{Асоціація ЕКГ-феноменів ранньої реполяризації і «-infantile» з вегетативною регуляцією серцевого ритму в юних спортсменів}

\section{Є. А. Михалюк, В. В. Сиволап, А. М. Гуніна, М. С. Потапенко, А. Аль Каддах}

Частота вегетативних розладів у спортсменів коливається в широкому діапазоні- від 6,2 \% до 36,5 \%. 3 підвищенням спортивної кваліфікації частота й тяжкість вегетативної дисфрункції збільшуються. Різні ЕКГ-френомени, зокрема СРРШі «Т-infantile», мають зв'язок із типом вегетативного тонусу. Диссункція АНС не визначає ґенез, а тільки зумовлює прояву ознак цих синдромів. Відкритими залишаються питання зв'язку ЕКГ-феноменів із характером вегетативної диссуннцції, віком і статтю спортсменів.

Мета роботи - вивчити частоту виявлення ювенільного зубця Т і СРРШ, їхньої асоціації з вегетативною регуляцією серцевого ритму в юних спортсменів у віковому діапазоні від 6 до 17 років.

Матеріали та методи. Здійснили електрокардіографічне дослідження та запис 5-хвилинних інтервалів варіабельності серцевого ритму у 3720 дітей і підлітків віком від 6 до 17 років, хлопців - 74,6 \% ( $n=2774)$, дівчат - 25,4 \% ( $n=946)$, які займаються різними видами спорту.

Результати. Феномен «T-infantile» виявили у 1,5 \% (56/3720) спортсменів, 3-поміж них 1,07 \% ( $n=40)$ хлопців і 0,43 \% ( $n=16)$ дівчат. У 5 (12,5\%) спортсменів «T-infantile» поєднувався з неповною блокадою правої ніжки пучка Гіса, у 3 (7,5\%) із синдромом укороченого PQ, у 1 (2,5 \%) - з синдромом ранньої реполяризації шлуночків. Крім ЕКГ-ознак «Т-infantile» у $3(18,75 \%)$ спортсменок додатково зафріксована неповна блокада ПНПГ, в 1 (6,25 \%) спортсменки зафіксували синдром укороченого PQ. Протягом порівняльного аналізу показників ВCP у хлопців і дівчат із феноменом «T-infantile» з'ясували: у хлопців вірогідно більша величина Д, що показує активність вагусної регуляції ритму серця $(0,403 \pm 0,028$ с проти 0,311 $\pm 0,025$ c, p = 0,019). Оцінюючи вегетативний стан за Р. М. Баєвським у спортсменів з ЕКГ-френоменом «Т-infantile», встановили: у $40 \%(n=16)$ хлопців була ваготонія, у $50 \%(n=20)$ - ейтонія, в $10 \%(n=4)$ - симпатикотонія. 3-поміж дівчат $31,25 \%(n=5)$ ваготоників, $50 \%$ ( $n=8)$ ейтоників і $18,75 \%(n=3)$ симпатикотоників. 
Висновки. Синдром ранньої реполяризації шлуночків і «T-infantile» виявляють у випадку ваготонії порівняно частіше, ніж при інших варіантах вегетативного тонусу. Поєднання надлишкових парасимпатичних впливів із цими ЕКГ-феноменами спостерігають здебільшого в осіб чоловічої статі. Феномен «T-infantile» може поєднуватися в юних спортсменів із неповною блокадою правої ніжки пучка Гіса.

\section{Ассоциация ЭКГ-феноменов ранней реполяризации и "T-infantile" с вегетативной регуляцией сердечного ритма у юных спортсменов}

\section{Е. А. Михалюк, В. В. Сыволап, А. М. Гунина, М. С. Потапенко, А. Аль Каддах}

Частота встречаемости вегетативных расстройств у спортсменов колеблется в широком диапазоне - от 6,2 \% до $36,5 \%$. С ростом спортивной квалификации частота и тяжесть вегетативной дисфункции увеличиваются. Различные ЭКГ-феномены, в том числе СРРЖ и «T-infantile» имеют сопряженность с типом вегетативного тонуса. При этом дисфункция АНС не определяет генез, а только способствует проявлению признаков этих синдромов. Открытыми остаются вопросы связи ЭКГ-феноменов с характером вегетативной дисфункции, возрастом и полом спортсменов.

Цель работы - изучить частоту встречаемости ювенильного зубца Т и СРРЖ, их ассоциации с вегетативной регуляцией сердечного ритма у юных спортсменов в возрастном диапазоне от 6 до 17 лет.

Материалы и методы. Проведено электрокардиографическое исследование и запись 5-минутных интервалов вариабельности сердечного ритма у 3720 детей и подростков в возрасте от 6 до 17 лет, мальчиков - 74,6 \% ( $n=2774)$, девочек$25,4 \%$ ( $n=946)$, занимающихся различными видами спорта.

Результаты. Феномен «T-infantile» обнаружен у $1,5 \%$ (56/3720) спортсменов, из них 1,07 \% ( $n=40)$ мальчиков и 0,43 \% ( $n=16)$ девочек. У 5 (12,5\%) спортсменов «T-infantile» сочетался с неполной блокадой правой ножки пучка Гиса, у 3 (7,5 \%) - с синдромом укороченного PQ, у 1 (2,5 \%) - с синдромом ранней реполяризации желудочков. Кроме ЭКГ признаков «T-infantile» у $3(18,75 \%)$ спортсменок дополнительно зафиксирована неполная блокада ПНПГ, а у одной спортсменки (6,25 \%) обнаружен синдром укороченного PQ. Сравнительный анализ показателей ВСР у мальчиков и девочек c феноменом «T-infantile» показал, что у мальчиков достоверно больше величина Д, отражающая активность вагусной регуляции ритма сердца $(0,403 \pm 0,028$ с против $0,311 \pm 0,025 \mathrm{c}, \mathrm{p}=0,019)$. При оценке вегетативного состояния по Р. М. Баевскому у спортсменов с ЭКГ-феноменом «Т-infantile» установлено, что у $40 \%(n=16)$ мальчиков имела место ваготония, у 50 \% ( $n=20)$ - эйтония, у $10 \%(n=4)$ - симпатикотония. Среди девочек было $31,25 \%$ ( $n=5)$ ваготоников, $50 \%(n=8)$ эйтоников, $18,75 \%(n=3)$ симпатикотоников.

Выводы. Синдром ранней реполяризации желудочков и «T-infantile» отмечают при ваготонии сравнительно чаще, чем при других вариантах вегетативного тонуса. Сопряжение избыточных парасимпатических влияний с этими ЭКГ-френоменами обнаруживают преимущественно у лиц мужского пола. Феномен «T-infantile» может сочетаться у юных спортсменов с неполной блокадой правой ножки пучка Гиса.

Scientific works concerning the study of "T-infantile" in children and adolescents are presented both in a cohort of young athletes [6], as well as their peers who are not involved in sports [23,24]. According to M. Gomirato-Sandrucci, G. Bono [17], "T-infantile" is a reflection of the epicardial right ventricular repolarization. "T-infantile" is characterized by inverted and biphasic T-waves in the right precordial leads, while such finding in syndrome of early ventricular repolarization (SEVR) is typical in the left precordial leads and less often in the limb leads. SEVR is associated with the presence of accessory pathway conduction. This phenomenon is a manifestation of atrioventricular conduction abnormalities with functioning of accessory atrioventricular or paranodal pathways.

In this case, a change in the autonomic nervous system tone is important. SEVR occurs when both the parasympathetic and the sympathetic divisions of the autonomic nervous system (ANS) predominate. It is believed that the ANS dysfunction does not determine the genesis, but only contributes to the syndrome signs manifestation. It is thought that SEVR, which is recorded in healthy individuals in the inferior leads in the presence of bradycardia, can serve as a reflection of an increased tone of the parasympathetic nervous system (PNS). However, the shortening of $P Q$, which is one of the frequent occurrence for SEVR, is not fully consistent with this concept [4].
Attempts to compare the changes in an autonomous homeokinesis found in athletes with the phenomenon of repolarization processes disturbances on the ECG were unsuccessful. According to I. M. Kurbanova, the presence of ST-T-shifts did not statistically significantly increase the frequency of the main symptoms of autonomous dysregulation in young athletes [8].

At the same time, there is convincing evidence that various ECG phenomena are associated with the type of autonomic tone. Signs of increased electrical activity of the left ventricular and right atrial myocardium, as well as lengthening of the electrical systole, are more common for an increased tone of the sympathetic nervous system (SNS). In case of an increased PNS tone, SEVR and pacemaker migration in the atria [8] are relatively more common than in other variants of autonomic tone.

It has been established that in the process of long-term adaptation of the athlete's body, the parasympathetic type of autonomic regulation of the cardiovascular system prevails, physiological hypertrophy of the left ventricle develops, the stroke volume increases, and the myocardial contractility improves. In the process of acute adaptation, adaptive mechanisms are improved, the economization of functions is increased and recovery processes are accelerated [7].

It has been shown that $3 / 4$ of young athletes have autonomic dysfunction with a predominance of cholinergic influences - more often with autonomic overactivity and in-
Ключевые слова: "T-infantile", юные спортсмены, вегетативный баланс.

\section{Запорожский} медицинский журнал. 2020. T. 22, № 3(120) C. $356-362$ 
sufficient autonomic provision for activity. Every third athlete is diagnosed with autonomic dysfunction type with increased sympathetic tone associated with more pronounced shifts in the parameters of autonomous homeokinesis. Moreover, with the improving sport qualification, the frequency and severity of autonomic dysfunction increase [8].

The incidence of autonomic disorders in athletes varies widely from $6.2 \%$ to $36.5 \%$. In the last decade, the prevalence of autonomic disorders has trended upwards in athletes due to an increase in psychophysical stress, environmental condition deterioration, as well as a number of negative social phenomena [9].

The above facts gave occasion to study the relationship between ECG - phenomena "T-infantile" and SEVR and autonomic regulation in young athletes.

\section{Aim}

The aim was to study the incidence of juvenile T-wave and SEVR, their association with the heart rate autonomic regulation in young athletes aged between 6 and 17 years.

\section{Materials and research methods}

An electrocardiographic study and recording of the heart rate variability using an automated complex "Cardio+" were carried out in 3720 children and adolescents aged between 6 and 17 years, of them $74.6 \%$ were boys $(n=2774)$ and $25.4 \%$ were girls $(n=946)$, engaged in various sports.

The girls were significantly older than boys $(11.1 \pm 0.68$ years versus $9.3 \pm 0.27$ years, $P=0.02$ ). There were 10 (25\%) boys at the age of 9 years old, $8(20 \%)$ at the age of 10 years, $6(15 \%)$ children each at the age of 8 and 11 years old, $4(10 \%)$ children at the age of 7 years, $3(7.5 \%)$ - at the age of 12 years, $2(5 \%)$ - at the age of 6 years and one $(2.5 \%)$ teenager aged 15 years. There were $4(25 \%)$ girls at the age of 11 years, $3(18.75 \%)$ girls each at the age of 9 and 12 years, and one (6.25\%) girl each aged $7,8,10$, 13,16 and 17 years.

Boys were involved in the following sports: martial arts (karate, taekwondo, jujitsu, kickboxing, hand-to-hand fighting) - $22(55 \%)$, sports games (football, hockey, table tennis) $-8(20 \%)$, horting $-4(10 \%)$, diving $-3(7.5 \%)$, swimming $-2(5 \%)$, fencing $-1(2.5 \%)$. Girls were engaged in sports games (basketball, handball, volleyball) -5 $(31.25 \%)$, swimming $5(31.25 \%)$, martial arts (wushu, karate) - 2 (12.5\%), and one person from each (6.25\%) diving, sports aerobics, rhythmic gymnastics and archery.

In order to assess the state of the neurohumoral regulation mechanisms of the heart, activity of segmental and suprasegmental parts of the ANS, mathematical and spectral methods for analyzing heart rate variability (HRV) were used [10]. In the analysis of HRV, short (5-minute) records were measured in accordance with the International Standard [22].

Analysis of the ANS indices was performed using an integral index of HRV, which was a stress index (SI). According to the recommendation of R. M. Baevsky [2] with SI values less than 50 rel. units, the state was regarded as increased PNS tone, within 51-199 rel. units - as normal ANS tone and the state of increased SNS tone was seen to be at SI above 200 rel. units.
The results were statistically processed using the Statistica for Windows 13 (StatSoft Inc., № JPZ804I382130ARCN10-J) employing parametric methods. The values were given as mean $(M) \pm$ standard error of the mean $(\mathrm{m})$. P not exceeding 0.05 was considered as a level of statistically significant differences between indices.

\section{Results}

Out of the total number of 3720 athletes, there were 56 people with "T-infantile" phenomenon, which amounted to $1.5 \%$, including $40(1.07 \%)$ boys and $16(0.43 \%)$ girls.

The greatest number of young athletes with juvenile T-wave on the ECG was among boys aged 9-10 years and among 9-, 11-and 12-year-old girls. The most common types of sports practicing by boys and girls were mainly martial arts and sports games, despite the fact that an earlier starting age with sports is currently common for all types of gymnastics (rhythmic, athletic, aesthetic) and diving. The differences in "T-infantile" incidence among young athletes, as compared with the data of other authors, can be attributed to the analysis of different cohorts of athletes involved in other sports, and a number of gender-related factors (hormonal, autonomic, etc.).

The analysis of ECG features in young athletes with the "T-infantile" phenomenon revealed the following.

In boys with "T-infantile" $(n=40)$, normal sinus rhythm was found in $80 \%$ ( $n=32)$ of cases, right atrial rhythm was in $20 \%(n=8)$. Rhythm regularity was assessed in $80 \%$ $(n=32)$, and in $20 \%(n=8)$ - sinus respiratory arrhythmia. Normal voltage on ECG was recorded in all boys. In boys with T-infantile, the electrical heart axis was not deviated in $30 \%(n=12)$, it was in a semi-vertical position in $30 \%$ $(n=12)$, in vertical position - in $25 \%(n=10)$, right axis deviation was in $7.5 \%(n=3), 5 \%(n=2)$ had a semi-horizontal position and left axis deviation was in one $(2.5 \%)$ person. Bradycardia was detected in $15 \%(n=6)$, 2 equal $42.5 \%$ groups (17 athletes each) had heart rate ranging from 61 to 79 beats/min and more than 80 beats/min in each one.

In five $(12.5 \%)$ athletes, "T-infantile" was combined with incomplete right bundle branch block (RBBB), in 3 (7.5\%)with short $P Q$ syndrome and in one $(2.5 \%)$ - with SEVR.

In girls with "T-infantile" $(n=16)$, normal sinus rhythm was found in $87.5 \%(n=14)$ of cases, right atrial rhythm was in $12.5 \%(n=2)$. Regular rhythm was found in $75 \%$ $(n=12)$ of athletes and respiratory sinus arrhythmia was in $25 \%(n=4)$. Normal voltage on ECG was measured in all girls. In $43.75 \%$ ( $n=7$ ) of young athletes, the electrical axis of the heart was in semi-vertical position, it was not deviated in $25 \%$ ( $n=4)$ of athletes, its vertical position was in $25 \%(n=4)$ and right axis deviation was in one $(6.25 \%)$ case. Bradycardia was detected in $12.5 \%(n=2)$, heart rate within $61-79$ beats $/ \mathrm{min}$ - in $50 \%(n=8)$ and in $37.5 \%$ $(n=6)$, heart rate was 80 beats/min and more.

In addition to the ECG signs of "T-infantile", incomplete RBBB was seen in three (18.75\%) athletes, and one athlete (6.25\%) showed short PQ syndrome.

A comparative analysis of HRV indices in boys and girls with the "T-infantile" phenomenon found that the D value was significantly higher in boys, reflecting an active vagal control of the heart rhythm regulation $(0.403 \pm 0.028 \mathrm{~s}$ versus $0.311 \pm 0.025 \mathrm{~s}, \mathrm{P}=0.019$ ). 
Also in boys, there was a tendency to decrease in the values of a number of indicators: AMo, which reflects the measure of the mobilizing influence of the sympathetic part $(36.321 \pm 2.059 \%$ versus $40.200 \pm 4.465 \%$, $\mathrm{P}=0.425) ; \mathrm{AMo} / \mathrm{D}$ - index indicating a relationship between the sympathetic and parasympathetic parts activity $(122.80 \pm 16.18 \% / \mathrm{s}$ versus $167.97 \pm 37.58 \% / \mathrm{s}, \mathrm{P}=0.269)$; autonomic rhythm index (ARI), indicating a balance of the autonomic sinus node regulation (4.363 $\pm 0.3761 / \mathrm{s}^{2}$ versus $\left.5.307 \pm 0.7611 / \mathrm{s}^{2}, P=0.265\right)$; index of adequacy of regulatory processes (IARP) showing a correspondence between the sympathetic part of the ANS activity and the leading level of the sinus node function $(52.869 \pm 3.577 \% / \mathrm{s}$ versus $58.814 \pm 8.566 \% / \mathrm{s}, \mathrm{P}=0.517$ ); stress index (SI) indicating a centralization degree of the heart rate control (90.835 \pm 12.904 conventional units versus $127.226 \pm 32.763$ conventional units, $P=0.300)$ and LF/HF sympatho-vagal index $(1.159 \pm 0.188$ conventional units against $1.413 \pm 0.282$ conventional units, $P=0.450$ ). The results obtained are indicative of the parasympathetic effects of ANS prevalence in boys with the phenomenon of "T-infantile".

Assessment of the autonomic state according to the classification of R. M. Baevsky (1997) found that in athletes with the ECG phenomenon of "T-infantile", $40 \%$ ( $n=16)$ of boys had increased PNS tone, $50 \%(n=20)$ had normal ANS tone, and $10 \%(n=4)$ - increased SNS tone. In girls, there were $31.25 \%(n=5)$ with increased PNS tone, $50 \%(n=8)$ with normal ANS tone and $18.75 \%$ $(n=3)$ with increased SNS tone, respectively. Thus, persons with normal ANS tone (50\% each) predominated in the studied groups, which corresponded to the value of SI 51-199 conventional units.

\section{Discussion}

The following signs are characteristic for "T-infantile": 1) negative T-wave or a negative phase of two-phased T-wave progressive decrease from lead V1 to lead V4;2) the apices of negative T-waves or the apices of negative phases of two-phased T-waves in the right precordial leads coinciding or slightly exceeding positive T-waves apices in the left precordial leads; 3 ) the central depth of T-wave in lead V3 or V4, giving a two-humped shape to it, coincidence with the top of positive T-wave in leads V5, V6; 4) ST segment is on the isoelectric line in the right chest leads without upward convex pattern.

According to N. A. Skuratova [14], signs of "T-infantile" are: 1) negative T-wave apices in the right chest leads coincide (or slightly precede) with positive T-waves in the left chest leads; 2 ) a reduction in the depth of T-waves negative phase from V1 to V4; 3) the central depth of T-wave coincidence (with two-humped occurrence) in the right precordial leads with the apex of TV5 and TV6 waves; 4) the absence of an arcuate ST segment elevation in the chest leads of the ECG. The described ECG changes in young athletes are a variant of the norm, that have nothing to do with ECG manifestations of cardiomyopathy due to chronic physical stress $[1,6]$.

Elevation of ST segment in combination with negative T-wave in the right chest leads is often detected in black athletes, less often in people with fair skin, and can imitate acute myocardial ischemia. Changes in repolarization in the left chest leads, including ST depression, should be evaluated at different phases of the training cycle, as such changes may be indicative of cardiomyopathy due to physical overstrain in an athlete [18].

In healthy trained athletes, T-waves recorded on an ECG can be high and sharpened, smoothed or isoelectric, prolonged or biphasic as well as inverted. Normally, the amplitude of T-wave changes during physical exercise. With good adaptation to the load, the amplitude of T-wave either remains at the initial level or even slightly increases. If the subject does not tolerate this load, the amplitude of T-wave begins to decrease. Such shifts become larger with a pulse exceeding 150-160 beats/min [13].

The literature data indicate a higher frequency of "T-infantile" registration in healthy children of both sexes aged 7-12 years, with a decrease in the percentage of this ECG phenomenon by 13-17 years. So, according to V. R. Abramova [1], "T-infantile" is registered in $25 \%$ of girls aged $11-12$, in $16.6 \%$ of boys aged $11-12$ years and in $12.5 \%$ at the age of $13-14$ years. M. Gomirato-Sandrucci, G. Bono [17] found "T-infantile" in $30 \%$ of healthy children and adolescents under the age of 14 years, while A. V. Shiyan [16] registered "T-infantile" among 7-9-year-old children in $21.7 \%$, and among $13-15$-year-old in $1.5 \%$.

A. Pelliccia et al. [21] analyzed the incidence of ECG abnormalities in individuals involved in amateur sports. The survey results of 32652 athletes ( $80 \%$ of men) were presented. T-wave inversion in more than two precordial and / or standard leads was detected in $(n=751 ; 2.3 \%)$; overexcitation syndrome - in ( $n=42 ; 0.1 \%)$; PR interval prolongation, incomplete RBBB pattern, premature repolarization, corresponding to 2280 athletes (7\%), predominantly $(>75 \%)$ in young athletes and in those aged over 30 years. 1170 athletes (3.6\%) presented rhythm abnormalities - sinus bradychardia predominated in $340(1 \%)$; supraventricular premature beats in 377 (1.1\%); ventricular premature beats in $349(1.1 \%)$; supraventricular tachycardia in 29 (0.09\%); atrial flutter or fibrillation in $5(0.02 \%)$; polymorphic ventricular premature beats in $40(0.1 \%)$; non-sustained ventricular tachycardia in $3(0.01 \%)$; and second degree atrioventricular block type 1 in 14 (0.04\%).

Surely, it is not entirely correct to compare the results of our study and the data of A. Pelliccia et al. [21], since Italian researchers combined people under and above the age of 18 years into one group, while the cohort in our study included only children aged 8-17 years. Considering the fact that juvenile T-waves are more common in young people, we made an analogy between the results of these two studies. It should be emphasized that T-wave inversion in more than two precordial and / or standard leads was detected by $A$. Pelliccia et al. [21] in a slightly higher percentage of persons surveyed than it was in our study $(2.3 \%$ versus $1.5 \%)$. The differences in indices are probably due to an age-related heterogeneity and a variation in the sample size.

The frequency of ECG signs combinations detected by A. Pelliccia et al. [21] is also worth mentioning: prolonged PR interval, incomplete RBBB and SEVR. In almost $7 \%$ of the examined athletes, mainly $(75 \%)$ in young people, these three ECG abnormalities were recorded. We observed a combination of "T-infantile" with incomplete RBBB in $18.75 \%$ of cases in girls and $12.5 \%$ in boys. In addition 
to this, in boys "T-infantile" was combined with short PQ syndrome in $7.5 \%$ of cases and in $2.5 \%$ - with SEVR.

According to V. I. Pavlova et al., incomplete RBBB is recorded in $50 \%$ of healthy endurance-training athletes. The presence of QRS complex of more than 0.12 seconds or left bundle branch block requires further examination to exclude organic damage to the myocardium [11].

SEVR manifested by an elevation of both $\mathrm{J}$ point and ST segment, is observed in 8-9\% of athletes. It is necessary to differentiate between SEVR and ECG changes in acute pericarditis $[11,18]$.

Yu. L. Venevtseva and co-authors conducted an ECG examination of 252 students, including 120 Russian-speaking and 13 foreign girls, as well as 54 Russian-speaking and 65 foreign boys. The incidence of SEVR was $5.3 \%$ and $7.7 \%$ in girls, respectively, and $14.8 \%$ and $26.2 \%$ in boys, respectively. HRV was evaluated in all students with a calculation of generally accepted indicators in sitting and standing positions. As a study result, Russian-speaking young men with SEVR showed signs of a relative increase in the parasympathetic influences: on the background of a longer average cardio interval (936.2 \pm 42.6 and $809.0 \pm 19.3 \mathrm{~ms} ; \mathrm{P}=0.022)$, they had a lower LF / HF ratio $(1.03 \pm 0.30$ and $2.33 \pm 0.35 ; P=0,0047)$, relative wave power $\mathrm{LF} \%$ ( $\mathrm{P}=0.012), \mathrm{AMo} \%$, autonomic equilibrium index (AEI), index of adequacy of regulatory processes (IARP), autonomic rhythm index (ARI) and SI, and higher HF relative wave power $(41.1 \pm 6.9$ and $26.0 \pm 1.9 \% ; P=0.034)$, however girls showed only a tendency to such an increase due to a decrease in the LF/HF ratio and the relative power of the vasomotor LF waves in a past history, while there were no differences in orthostasis. SEVR on ECG in foreign young men may indicate an increase in sympathetic influences: the power of high-frequency HF wave in a past history was lower than in boys without this phenomenon $(P=0.048)$ with a tendency to increase in the LF/HF ratio $(P=0.051)$. There were no differences in orthostasis [3].

This way, Yu. L. Venevtseva and co-authors received a confirmation of the linkage between an increase in parasympathetic influences and SEVR in Russian-speaking young men. In the study, we also observed the association between increased PNS tone and the ECG-phenomenon "T-infantile" only in young athletes, such a relationship was not observed in girls.

E. V. Pshenichnaya and E. V. Prokhorov examined 547 teenage boys aged 15-16 years, who had come to a clinic to decide on an ability of practicing sport in sports sections, educational institutions with a high level of physical activity. A standard ECG was performed in $311(56.9 \pm 2.1 \%)$ adolescents with identified changes during an objective examination of the cardiovascular system. In $174(63.0 \pm 2.9 \%)$ children, cardiac arrhythmias and conduction disorders were detected: sinus tachycardia in $48(17.4 \pm 2.3 \%)$, sinus bradycardia in $43(15.6 \pm 2.2 \%)$, premature atrial contractions - in $34(12.3 \pm 2.0 \%)$, premature ventricular contractions - in $37(13.4 \pm 2.1 \%)$, atrioventricular block I - in 10 (3.6 $\pm 1.1 \%)$, the WPW phenomenon - in $2(0.7 \pm 0.5 \%)$. The spectrum of rhythm and conduction disorders and the frequency of their detection according to the standard ECG data did not fundamentally differ from the results of other authors. At the same time, during an additional 24-hour Holter monitoring for all adolescent boys with changes in the standard ECG, heart rhythm disturbances were detected only in 51 (9.3\%) examined [12].

Young athletes with the ECG-phenomenon "T-infantile" can present with cardiomyopathy. According to L. A. Butchenko [5], the following changes were revealed on the ECG in such cases: 1) the absence of a progressive decrease in negative T-wave or a negative phase of two-phased T-wave from lead V1 to lead V4, and even an increase in the negative T-wave or negative phase of the two-phased T-wave towards lead V3; 2) the appearance in one of the leads, more often in the leads V3, V4, of a negative or a positive flat T-wave; 3) final negativization of the T-wave; 4) upward convex pattern of ST-segment elevation. The ECG signs of cardiomyopathy described in young athletes can occur in various combinations.

F. Migliore et al. [19], when examining 2765 children (1914 male and 851 female) between 8 and 18 years old (average age $13.9 \pm 2.2$ years), recorded T-wave inversion in the right precordial leads in 131 children, which amounted to $4.7 \%$. The prevalence of "T-infantile" decreased significantly with increasing age (8.4\% of children under 14 years of age compared with $1.7 \%$ of those over 14 years of age, $P<0.001)$. Of 158 children with T-wave inversion, $4(2.5 \%)$ were diagnosed with cardiomyopathy, including arrhythmogenic cardiomyopathy of the right ventricle in three and hypertrophic cardiomyopathy in one. The authors suggest that T-wave inversion is a common ECG violation in hereditary heart muscle diseases, such as hypertrophic cardiomyopathy and arrhythmogenic right ventricular cardiomyopathy, which are the main causes of sudden cardiac death in young athletes.

These cardiomyopathies are genetically determined and show age-related phenotypic expression. Since the early manifestations of the disease usually occur after puberty, the persistence of T-wave inversion in post-puberty raises the problem of differential diagnosis between a developing heart muscle disease and a benign juvenile type of repolarization. In this age group, T-wave inversion, localized mainly in the right precordial leads, was documented in $5.7 \%$ of cases, decreased significantly with age, in the puberty, and, most importantly, was a sign of arrhythmogenic right ventricular and hypertrophic cardiomyopathy, verified in $2.5 \%$ of cases. These results showed that following the end of puberty, T-wave inversion is much less common than is widely assumed, and its persistence can indicate a heart muscle disease and a high risk of sudden cardiac death. Therefore, the post-puberty persistence of T-wave inversion in children involved in sports dictates the need for a mandatory echocardiographic examination with the aim of early preclinical verification of heart muscle pathology.

M. Papadakis et al. [20] examined 1710 adolescent athletes and 400 children not practicing sports (control group). The authors did not obtain significant differences in the overall prevalence of T-wave inversion between athletes and the control group ( $4 \%$ versus $3 \% ; P=0.46$ ). T-wave inversion in leads $\mathrm{V} 1-\mathrm{V} 3$ was mainly limited to both groups over the age of 16 years. Only $0.1 \%$ of athletes aged 16 years and older had T-wave inversions beyond V2. T-wave inversion in the inferior and / or lateral leads and deep T-wave inversion occurred infrequently in athletes $(1.5 \%$ and $0.8 \%$, respectively) and were associated with a high prevalence of left ventricular hypertrophy or congenital heart 
anomalies. Despite an in-depth examination, no athlete was diagnosed with a cardiomyopathy.

Telesheva I. A. and co-authors analyzed 849 ECGs of children aged from 4 months to 17 years who were in a hospital with various somatic diseases in the departments of rheumatology, endocrinology, nephrology, allergology, psychoneurology. Children did not present with complaints concerning cardiological symptoms. During the examination, the authors identified 3 groups of patients in whom the following ECG phenomena were recorded: pacemaker migration (PM), SEVR, supraventricular scallop syndrome (SSS). SSS was most commonly registered, in 40 patients (5\%), PM in 26 (3 \%), and SEVR - in 16 (2\%) patients. In none of the cases was a clinically significant cardiological pathology confirmed. The researchers concluded that PM, SEVR and SSS are prognostically and clinically favorable ECG phenomena even in children with concomitant somatic pathology, and do not require further examination and treatment [15].

Thus, SEVR and "T-infantile" are more common in increased PNS tone than in other variants of autonomic tone. A combination of parasympathetic overactivity with these ECG phenomena is observed mainly in males. The phenomenon of "T-infantile" in young athletes of both sexes can be combined with an incomplete RBBB.

\section{Conclusions}

1. The prevalence of "T-infantile" among young athletes aged between 6 and 17 years was $1.50 \%, 1.07 \%$ in boys and $0.43 \%$ in girls.

2. The highest percentage of young athletes with "T-infantile" was among 9- and 10-year-old boys and among 9-, 11 - and 12-year-old girls.

3. In five (12.5\%) athletes, "T-infantile" was combined with incomplete right bundle branch block, in $3(7.5 \%)$ with short PQ syndrome and in one $(2.5 \%)$ - with early repolarization syndrome.

4. The phenomenon of "T-infantile" was combined with incomplete right bundle branch block in three $(18.75 \%)$ athletes and with short QT syndrome in one $(6.25 \%)$.

5. HRV data indicate the predominance of parasympathetic influences of the autonomic nervous system in boys with the ECG phenomenon "T-infantile", while $50 \%$ of boys and girls with juvenile T-wave have a state of normal ANS tone.

Prospects for further research are to study the effect of exercise on the electrophysiological properties of the myocardium in athletes.

Conflicts of interest: authors have no conflict of interest to declare. Конфлікт інтересів: віАсутній.

Надійшла Ао редакції / Received: 31.01.2020

Після Аоопрацювання / Revised: 04.02.2020

Прийнято Ао Аруку / Accepted: 17.02.2020

Information about authors:

Mykhaliuk Ye. L., MD, PhD, DSc, Professor, Head

of the Department of Physical Rehabilitation, Sports Medicine,

Physical Education and Health, Zaporizhzhia State Medical

University, Ukraine.

ORCID ID: 0000-0003-3607-7619
Syvolap V. V., MD, PhD, DSc, Professor, Head of the Department of Propedeutic Internal Medicine, Radiation Diagnostic and Radiation Therapy, Zaporizhzhia State Medical University, Ukraine. ORCID ID: 0000-0001-9865-4325

Hunina L. M., PhD, DSc, Professor, Deputy Director

of the Educational and Scientific Olympic Institute of the National University of Physical Education and Sports of Ukraine, Kyiv.

Potapenko M. S., MD, PhD, Assistant of the Department of Anesthesiology and Intensive Care, Zaporizhzhia State Medical University, Ukraine.

Diana Al Kaddah, MD, second-year internship doctor, Department of Propedeutic Internal Medicine, Radiation Diagnostic and Radiation Therapy, Zaporizhzhia State Medical University, Ukraine.

\section{Відомості про авторів:}

Михалюк Є. ^., А-р меА. наук, професор, зав. каф. фізичної реабілітації, спортивної медицини, фізичного виховання і зАоров'я, Запорізький Аержавний медичний університет, Україна.

Сиволап В. В., А-р меА. наук, професор, зав. каф. пропедевтики внутрішньої меАицини, променевої Аіагностики та променевої терапії, Запорізький державний медичний університет, Україна. Гуніна $\Lambda$. М., А-р біол. наук, професор, заступник директора Навчально-наукового олімпійського інституту, Національний університет фізичного виховання і спорту України, м. Київ. Потапенко М. С., канА. меА. наук, асистент каф. анестезіології та інтенсивної терапії, Запорізький державний медичний університет, Україна.

Аіана Аль КадАах, лікар-інтерн Аругого року навчання на каф. пропедевтики внутрішньої медицини, променевої Аіагностики та променевої терапії, Запорізький Аержавний медичний університет, Україна.

\section{Сведения об авторах:}

Михалюк Е. ^., А-р меА. наук, профессор, зав. каф. физической реабилитации, спортивной меАицины, физического воспитания и зАоровья, Запорожский госуАарственный меАицинский университет, Украина.

Сыволап В. В, А-р меА. наук, профессор, зав. каф. пропедевтики внутренней медицины, лучевой Аиагностики и лучевой терапии, Запорожский государственный медицинский университет, Украина.

Гунина ^. М., А-р биол. наук, профессор, зам. Аиректора Учебнонаучного олимпийского института, Национальный университет физического воспитания и спорта Украины, г. Киев.

Потапенко М. С., канА. меА. наук, ассистент

каф. анестезиологии и интенсивной терапии, Запорожский государственный медицинский университет, Украина. Аиана Аль Кадаах, врач-интерн второго года обучения на каф. пропедевтики внутренней медицины, лучевой Аиагностики и мучевой терапии, Запорожский государственный медицинский университет, Украина.

\section{References}

[1] Abramova, V. R. (2006). Morfofunktsional'nyye osobennosti adaptatsi i uroven' fizicheskoy podgotovlennosti organizma yunykh sportsmenov 11-16 let korennogo naseleniya Respubliki Sakha (Yakutiya) : avtoref. dis. ... kand. biol. nauk : spets. 03.00.13 [Morphological and functional features of adaptation and the level of physical fitness of the body of young athletes 11-16 years old of the indigenous population of the Republic of Sakha (Yakutia)]. Extended abstract of candidate's thesis. Tyumen State University. [in Russian].

[2] Baevskii, R. M., \& Berseneva, A. P. (1997). Otsenka adaptatsionnykh vozmozhnostei organizma i risk razvitiya zabolevanii [Assessment of the adaptive capabilities of the body and the risk of developing diseases]. Moscow: Meditsina. [in Russian].

[3] Venevtseva, Yu. L., Balko, A. S., \& Mel'nikov, A. Kh. (2019). Osobennosti vegetativnogo statusa molodykh lyudey s EKG-fenomenom ranney repolyarizatsii zheludochkov serdtsa [Features of the vegetative status of young people with an ECG phenomenon of early repolarization of the ventricles of the heart]. Rossiiskii kardiologicheskii zhurnal, (4s2). 13. [in Russian].

[4] Gorokhov, S. S. (2013). Sindrom ranney repolyarizatsii zheludochkov na EKG - sovremennoye sostoyaniye voprosa: Soobshcheniye 1. [The syndrome of early ventricular repolarization on the ECG - the current state of the issue: Message 1]. Voyennaya meditsina, (4), 117-124. [in Russian]. 
[5] Tikhvinskii, S. B., \& Khrushchev, S. V. (Eds). (1991). Detskaya sportivnaya meditsina [Children's sports medicine] (2nd ed.). Moscow: Meditsina. [in Russian]

[6] Butchenko, L. A., Kushakovskii, M. S., \& Zhuravleva, N. B. (1980). Distrofiya miokarda u sportsmenov [Myocardial dystrophy in athletes] Moscow: Meditsina. [in Russian].

[7] Iordanskaya, F. A., Buchina, Ye. V., \& Tsepkova, N. K. (2016). Vozrastnye polovye osobennosti adaptatsii serdechno-sosudistoi i vegetativno-nervnoi sistem $v$ obespechenii rabotosposobnosti grebtsov akademistov [Age and sex characteristics of adaptation of the cardiovascular and autonomic nervous system in ensuring the health of rowers rowing]. Vestnik sportivnoi nauki, (3), 23-29. [in Russian].

[8] Kurbanova, I. M. (2002). Funktsional'noe sostoyanie vegetativnoi nervno i serdechno-sosudistoi sistem u yunykh sportsmenov : dis. kand. med. nauk: 14.00.09 Pediatriya [The functional state of the autonomic nervous and cardiovascular systems in young athletes]. Extended abstract of candidate's thesis. Ivanovo State Medical Academy. [in Russian].

[9] Mitin, M. S. (2015). Rasprostranennost' i vyrazhennost' vegetativnoi disfunktsii sredi molodykh sportsmenov [The prevalence and severity of autonomic dysfunction among young athletes]. Nauchnyi rezul'tat. Seriya Meditsina i farmatsiya,1(2), 30-38. [in Russian].

[10] Mikhaylov, V. M. (2002). Variabel'nost' ritma serdtsa: opyt prakticheskogo primeneniya metoda [Heart rate variability: experience of the practical application of the method]. ( $2^{\text {nd }}$ ed.). Ivanovo: Ivanovo State Medical Academy. [in Russian].

[11] Pavlov, V. I., Pachina, A. B., Ivanova, Yu. M., \& Sharoiko, M. V. (2009). Otsenka elektrokardiograficheskikh izmenenii pri dispanserizatsii sportsmenov [Assessment of electrocardiographic changes during medical examination of athletes]. Vestnik aritmologii, (Suppl. A), 163164. [in Russian]

[12] Pshenichnaya, Ye. V., \& Prokhorov, Ye. V. (2019). Narusheniya ritma serdtsa u uslovno-zdorovykh mal'chikov-podrostkov predprizyvnogo vozrasta [Heart rhythm disturbances in conditionally healthy teenage boys of business age]. Rossiiskii kardiologicheskii zhurnal, 24(Suppl.), 18. [in Russian].

[13] Skuratova, N. A. (2010). Sportivnoye serdtse [Athletic heart]. Problemy zdorov'ya i ekologii, (2), 71-77. [in Russian].

[14] Skuratova, N. A. (2016). Sindrom rannei repolyarizatsii zheludochkov u detei i podrostkov: diagnosticheskii algoritm pri dopuske $\mathrm{k}$ fizicheskim nagruzkam [Early repolarization syndrome in children and adolescents: diagnostic algorithm to allow children to do physical exercise]. Problemy zdorov'ya i ekologii, (4), 96-100. [in Russian].

[15] Telesheva, I. A., Makarov, L. M., \& Komolyatova, V. N. (2019). Klinicheskoe znachenie nekotorykh EKG-fenomenov u detei s somaticheskoi patologiei [Clinical significance of some ECG phenomena in children with somatic pathology]. Rossiiskii kardiologicheskii zhurnal, 24(Suppl.), 15. [in Russian].

[16] Shiyan, A. V. (2005). Osobennosti funktsional'nogo sostoyaniya serdechno-sosudistoi sistemy i vegetativnogo statusa u detei i podrostkov : avtoref. dis. ... kand. biol. nauk: spets. 03.00.13 [Features of the functional state of the cardiovascular system and autonomic status in children and adolescents]. Extended abstract of candidate's thesis. Kuban State University of Physical Education, Sport and Tourism. [in Russian]

[17] Sandruchchi, M. G., \& Bono, G. (1966). Elektrokardiografiya v detskom vozraste s elementami fonokardiografii i ballistokardiografii [Electrocardiography in childhood with elements of phonocardiography and ballistic cardiography]. Moscow: Meditsina. [in Russian].

[18] Corrado, D., Pelliccia, A., Bjornstad, H. H., Vanhees, L., Biffi, A. Borjesson, M., ... Thiene, G. (2005). Cardiovascular pre-participation screening of young competitive athletes for prevention of sudden death: proposal for a common European protocol - Consensus statement of the Study Group of Sport Cardiology of the Working Group of Cardiac Rehabilitation and Exercise Physiology and the Working Group of Myocardial and Pericardial Diseases of the European Society of Cardiology. European Heart Journal, 26(5), 516-524. https://doi. org/10.1093/eurheart/ehi108

[19] Migliore, F., Zorzi, A., Michieli, P., Marra, M. P., Siciliano, M., Rigato, I. Bauce, B., Basso, C., Toazza, D., Schiavon, M., Iliceto, S., Thiene, G., \& Corrado, D. (2012). Prevalence of Cardiomyopathy in Italian Asymptomatic Children With Electrocardiographic T-Wave Inversion at Preparticipation Screening. Circulation, 125(3), 529-538. https://doi. org/10.1161/circulationaha.111.055673

[20] Papadakis, M., Basavarajaiah, S., Rawlins, J., Edwards, C., Makan, J., Firoozi, S., Carby, L., \& Sharma, S. (2009). Prevalence and significance of T-wave inversions in predominantly Caucasian adolescent athletes. European Heart Journal, 30(14), 1728-1735. https://doi.org/10.1093/ eurheartj/ehp164

[21] Pelliccia, A., Culasso, F., Di Paolo, F. M., Accettura, D., Cantore, R. Castagna, W., ... Di Luigi, L. (2007). Prevalence of abnormal electrocardiograms in a large, unselected population undergoing pre-participation cardiovascular screening. European Heart Journal, 28(16), 2006-2010. https://doi.org/10.1093/eurheartj/ehm219
[22] Heart rate variability: standards of measurement, physiological interpretation and clinical use. Task Force of the European Society of Cardiology and the North American Society of Pacing and Electrophysiology. (1996). Circulation, 93(5), 1043-1065.

[23] Ziegler, R. F. (1951). Electrocardiographic Studies in Normal Infants and Children. Springfield, Illinois, Charles C Thomas Publisher.

[24] Zuckermann, R. (1959). Grundri und Atlas der Electrocardiographie. Leipzig: Verlag Georg Thieme. 